\title{
脊椎脊葡疾患に対する術中超音波検查の有用性
}

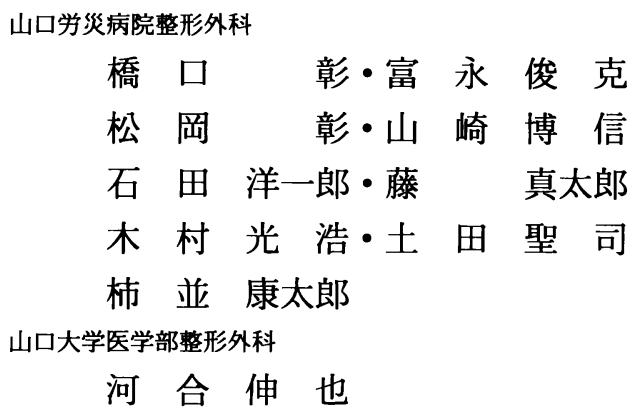

\section{Utility of Intraoperative Spinal Sonography for Spinal Disease}

\author{
Akira Hashiguchi, Toshikatsu Tominaga, Akira Matsuoka, \\ Hironobu Yamasaki, Yoichiro Ishida, Shintaro Toh, \\ Koji Kimura, Seiji Tsuchida and Kotaro Kakinami \\ Department of Orthopedic Surgery, Yamaguchi Rosai Hospital, Japan

\section{Shinya Kawai}

Department of Orthopedic Surgery, School of Medicine, Yamaguchi University, Japan

The purpose of this study is to clarify the usefullness of intraoperative spinal sonography (IOSS) for spinal diseases.

Our IOSS procedure is as follows ; 1) After laminectomy or laminoplaty, water is properly applied over the dura surface, 2) The probe used for IOSS is the $7.5 \mathrm{MHz}$ Toshiba probe, 3 ) Scanning of acurate sagittal and axial images.

More information the spinal cord can be obtained using IOSS than MRI imaging in some cases. IOSS provides an excellent visualization of the spinal cord and anterior surface of the spinal canal. This method is therefore quite useful for monitoring the decompression of the spinal cord in cervical myelopathy and OPLL. We can also observe the position and extent of syrinx and evaluate the shunt, as well as observe the size of syrinx which changes with breathing in the case of syringomyelia. IOSS may play a significant role for solving the extending mechanism of syrinx.

IOSS has thus been concluded as being extremely useful for reconfirming the decompression of the spinal cord during real-time operations. This method also allows evaluation of dynamic spinal cord motion in various kinds of spinal diseases.

Key words : Intraoperative Spinal Sonography（術中脊逞超音波検査）, Cervical Myelopathy（頝䯣 症), Syringomyelia（脊䯣空洞症）

はじめに

超音波検查は苦痛や障害が少なく，軟部組織をよく
分解表示できるため, これまでに内科, 外科, 産婦人 科領域で広く用いられてきた. 近年, 整形外科領域で も, 腫瘍・股関節疾患・術中脊䯣エコー等を中心にそ 
の臨床への応用がなされてきている，私達は脊䯣脊椎 疾患において, 術中に除圧状態を適切に把握する手段 として脊䯣超音波検查を施行しており，その有用性に ついて若干の考察を加えて報告する.

\section{対象および方法}

対象は平成 4 年から平成 9 年の間に椎弓切除ないし 椎弓形成術を行った脊髄疾患 124 例である. 使用機器 は東芝社製 SSA-250A で，プローブは周波数 $7.5 \mathrm{MHz}$ リニア型を用いた。

術中超音波検查は椎弓切除もしくは椎弓形成術を行 い硬膜を露出した段階で，術野の硬膜外に生理食塩水 を満たして水浸法により, 脊䯣の縦断面と横断面の 2 方向断面像を観察した。

\section{結果}

中心性頝髄損傷においては MRI では脊䯣内に high intensity area を認めたのみの症例においても，術中 脊随超音波検查では内部に micro-cystic lesion を伴っ た hyper echogenic lesion を確認できるなど，ょり 詳細に脊檤内の変化を捉えることができた，頚䯣症や 後縦勒帯骨化症の症例では, 脊剈道圧迫病変の局在・圧 迫の程度，また除圧後の状態，特に脊䯣前方の除圧の 過不足を確認できる点できわめて有用であった（図1). また，腫瘍においては，その局在・広がりを確認とと もにある程度の質的判定も可能であった，さらに，脊 髄空洞症例では, 術中に空洞の局在・広がりの把握, また shunt の効果判定のみならず，呼吸性の変化を dynamic に捉えることができた（図2）.

\section{考察}

一般的に, 術中脊䯣エコーの利点は, 任意の部位・ 断面において，形態的評価のみならず動的な観察が行 え，しかも，それを real timeに評価できるという点 である1)．欠点としては，骨・ガスにより画像が著し く障害されるため, 脊椎疾患では骨性因子の除去を前 提としており，主に術中に用いられる.

従来, 脊髄除圧の確認は硬膜背側からの観察であり, 一般に，硬膜の拍動を指標にしてきた。しかし，必ず しもそうでない症例も認められる。そこで，直接的に くも膜下腔の拡がりや脊䯣の形態，春䯣拍動を観察す る事ができる術中超音波検查は除圧の評価を正確に行 える点で極めて有用な検查方法である，特に，春䯣拍

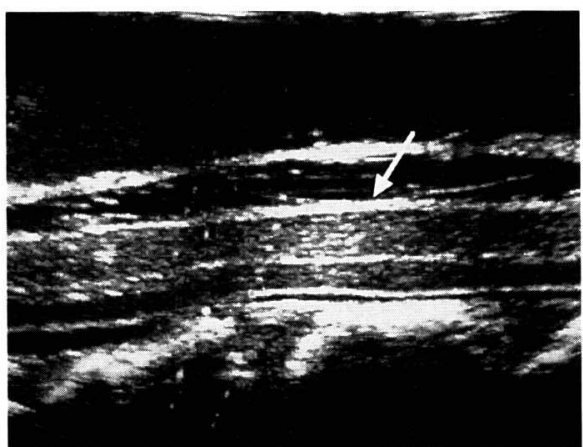

図 1 澒䯣症：〈あ膜下腔の拡がり，脊䯣拍動の観 察により除圧の確認が可能である。また, hyper echogenic lesionがみられ, 脊䯣内の変 性があると考えられる。

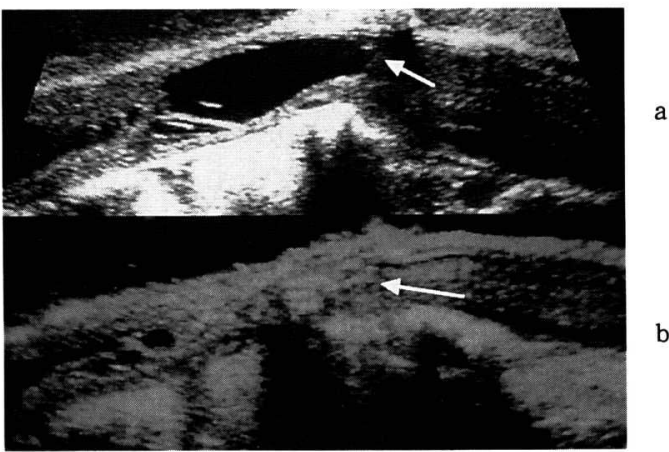

図 2 脊髄空洞症 : a , s-s shunt 前 b. s-s shunt 後: 空洞は cystic cavity として明瞭に描出され, s-s shunt により空洞の縮小を確認できる。

動の強さや拍動様式の観察が可能であるという点, す なわち形態的評価にとどまらず， dynamic な観察が 可能であるという点で他の画像検査にはない重要な利 点を有している，さらに，超音波検査を用いた春䝵拍 動の観察を基に予後予測の試みもされている．富永 ら 3)4) は脊檤拍動の強さや拍動様式は除圧の過不足に 加えて術中に抢ける脊椎アライメント, 脊柱管壁の状 態, 脊髄変性度などあ少なからず関与しているため, 一元的には術後成績とは相関しないものの，かなりの 程度に脊䯣予後判定の一助となるとしている.

また，術中脊檤エコーは空洞症のメカニズムなどへ の応用も検討されている河端ら 2) は術中に胸腔内圧を 上昇させると $30 \mathrm{cmH} 20$ 以上では，空洞は著名に拡 
大する事を確認しており，Williams の sloshing mechanism が空洞の進展・拉大に重要な役割を果た していることを証明している。しかし一方で, Queckenstedt 操作により空洞が樎小することも確認 しているが，そのメカニズムについては明らかにして おらず，未だ空洞進展のメカニズムは不明な点が多い。 私達の経験した空洞症例においても呼吸性に空洞の縮 小・拡大を観察しており，Williams の sloshing mechanism に矛盾しない，さらに私達の症例では空 洞が脊随腹側にチェックバルブを持っていることあ観 察することができ，今後空洞進展のメカニズムを解明 する上で, 超音波検査は必須の検査法である.

$$
\text { ま と め }
$$

今後, 高齢社会となり, 骨粗鬆症の進行した患者が 増加する中で, 比較的軽微な外傷による burst fractue 等が増加することが考えられる. そこで，脊 喵除圧を計画する際に, 除圧の程度を術中に real time に確認できる脊䯣エコーは唯一の検査法であり， その有用性は増してくると考える.さらに, 術中 real timeにしかす dynamic な観察が可能という利点を生 かして予後予測等様々な試みがなされており，今後脊 䯣エコーの意義を再検討する必要があると考える.

\section{参 考 文 献}

1）岩橋正樹，他：䯣膜腫と神経鞘腫の術中超音波像の差 異. Japanese Society of Orthopedic Ultrasonics Vol. 7, No.1 : 47-51, 1995.

2）河端博也，他 : 交通性脊榷空洞症の術中超音波診断に よる動態観察. Japanese Society of Orthopedic Ultrasonics Vol.1, No.1 : 50-52, 1989.

3）富永俊克，他：頝艏症に対する術中脊邻道エコーの形態 的・動態的観察之手術成績. Japanese Society of Orthopedic Ultrasonics Vol.1, No.1 : 53-55, 1989.

4）富永俊克，他：脊椎・春璡疾患に対する術中超音波検 查法の有用性. 骨・関節・靬帯 5 巻 4 号 : 453-457, 1992. 